and can avoid compaction by appropriate and timely cultivations, fertilizers can do a great deal to raise yields in these areas, as the older fertilizer experiments in China and India (references in Bunting, 1962), and those more recently initiated under the Fertilizer Program of the Freedom From Hunger Campaign, have demonstrated. Indeed, we cannot hope to solve the world food problem unless we make considerable use of fertilizers. Our current knowledge of the mode of action of organic manures and of the effects of soil organic matter does not suggest that we need have any inhibitions about using fertilizers on soils of inherently low organic matter content, provided the technology of fertilizer use is carefully worked out. This may well be very different, particularly in respect of phosphate and liming, from the practice of temperate countries. With the limited human resources at our disposal for work of this kind, the main effort must be on this front. The information we have does not call for a major diversion of research effort to organic manuring in the tropics at the present time, particularly as the land needed to grow organic matter with which to make organic manures would in many countries be far better used, with the aid of fertilizer and improved agronomic practices, to grow crops. A large part of the basis of the use of FYM, in the older systems of husbandry in Britain, was the importation of plant foods in cattle feed from other countries. The situation in developing countries today is quite otherwise: they do not import plant foods from elsewhere in animal feeds. They should, and of course often do, return to the land the plant foods contained in crop residues, and in urban and domestic wastes, so far as this is consistent with human health. But even in China, where such wastes are carefully returned to the land, the use of fertilizers is essential to future progress.

\title{
REFERENCES
}

Bunting, A. H. (1962). Proc. Nutr. Soc. 2r, 91.

Bunting, A. H. (1963). F. agric. Sci. 60, 121 .

Clement, C. \& Williams, T. E. (1965). F. agric. Sci. (In the Press.)

Cooke, G. W. (1963). Report of the Chemistry Department, in Rep. Rothamst. exp. Sta., I962.

Cooke, G. W. \& Garner, H. V. (I954). F. R. agric. Soc. rr5, 27.

Empire Cotton Growing Corporation (1958). Progr. Rep. Exp. Stas Emp. Cott. Gr. Corp., season $1956-57$.

Empire Cotton Growing Corporation (1964). Progr. Rep. Exp. Stas Emp. Cott. Gr. Corp., season $1962-63$.

Haworth, F. (1960). Chemistry report, in Rep. nat. Veg. Res. Sta. Wellesbourne, I 959.

Haworth, F. \& Nelder, J. A. (1954). Rep. nat. Veg. Res. Sta. Wellesbourne, 1953, p. 30.

Haworth, F. \& Nelder, J. A. (1955). Rep. nat. Veg. Res. Sta. Wellesbourne, 1954, p. 40.

Salter, P. J. \& Haworth, F. (196r). F. Soil Sci. 12, 326.

Salter, P. J. \& Williams, J. B. (1963). F. Soil Sci, 14, 73.

Whitehead, D. C. (1963). Soils \& Fert. 26, 217.

Williams, R. J. B. \& Cooke, G. W. (r96r). Soil Sci. 29, 30.

\section{The chemical composition of grasses in relation to agronomical practice}

\section{By R. WaIte, Hannah Dairy Research Institute, Ayr}

I should like first to consider the normal life cycle of a perennial grass growing without intervention by man, because the chemical composition of the grass utilized 
on the farm is generally the result of a compromise between how the farmer has treated it and the natural habit of growth of the species.

Beginning with an established but dormant winter sward, I shall assume that the grass receives sufficient cold to ensure that it will subsequently flower under the appropriate conditions of day-length and temperature. Development of the primary growing point in early spring will be accompanied by growth of the leaves, and for a few weeks the chemical composition of the plant is mainly that of the leaf blade and leaf sheath. Once the flower head emerges from within the leaf sheath, however, there is a rapid elongation of the stem and within $2-3$ weeks the leaf blades will contribute only $10-15 \%$ of the total dry matter of the plant. The relative proportions of leaf, sheath, stem and head that make up the plant are most important. Leaf dry matter is richer in nitrogen, lipid, carotene and mineral and poorer in soluble carbohydrates and lignin than the stem, although the percentages of structural carbohydrates, cellulose, and hemicelluloses in these two portions of the plant usually do not differ greatly (Waite \& Gorrod, I959). The chemical composition of leaf sheath is intermediate between that of leaf and stem (Johnston \& Waite, 1965).

In grass that is allowed to grow without check, the fall in $\mathrm{N}$ concentration and the rise in the concentrations of the structural carbohydrates and lignin proceed smoothly, but the changes in the group of soluble carbohydrates, glucose, fructose, sucrose and fructosan, which are frequently a major part of the plant, are much less predictable. This is understandable because these compounds are at once the end-products of photosynthesis, the starting point of protein formation and the providers of material for the energy metabolism and carbohydrate reserve in the plant. Changes in the fructosan concentration, for example, have been correlated with the development and growth of the flower initial (Waite, I963), and the proportion of active to dead leaves governs the amount of photosynthesis possible.

It is therefore against this background of continual change that the effect on plant composition of the various agronomic practices has to be considered.

\section{Grass for the grazing animal}

Cattle can utilize somewhat longer grass than sheep, but for both classes of animal the aim of the grazier is to provide a dense sward of easily digestible material. This means grass in which the flower head has not emerged, since in most grasses the fully developed stem has a considerably lower digestibility than the leaf, which not only reduces the amount of nutrients available for metabolism but also restricts intake. The chemical composition of good grazing grass therefore is essentially that of the leaf and leaf sheaths, in which the amount of lignified tissue is small. Figs. I and 2 show the percentages of crude protein, total soluble sugars, cellulose, lignin, ether extractives and ash in the dry matter of three varieties of ryegrass, two varieties of timothy and one each of meadow fescue and cocksfoot. All these grasses were in their 2 nd year of growth, had received the same liberal treatment with fertilizer and were cut each time they reached a height of 9 in.

It will be seen that for most of the grasses the percentage of $\mathrm{N}$ increased after the second cutting. In these summer and autumn grasses growth was entirely vegetative, 

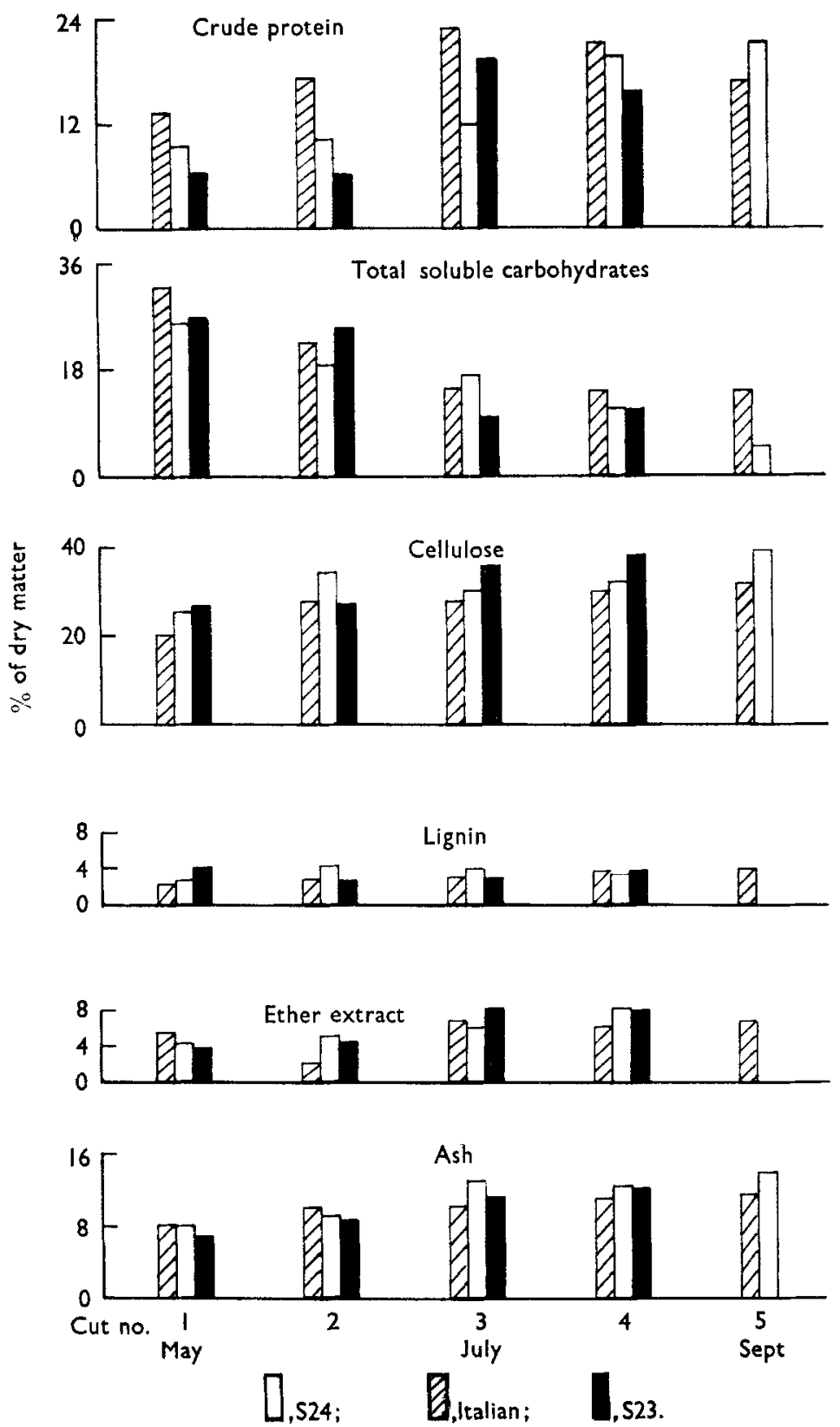

Fig. 1. Composition of three varieties of ryegrass cut each time they reached grazing height, 

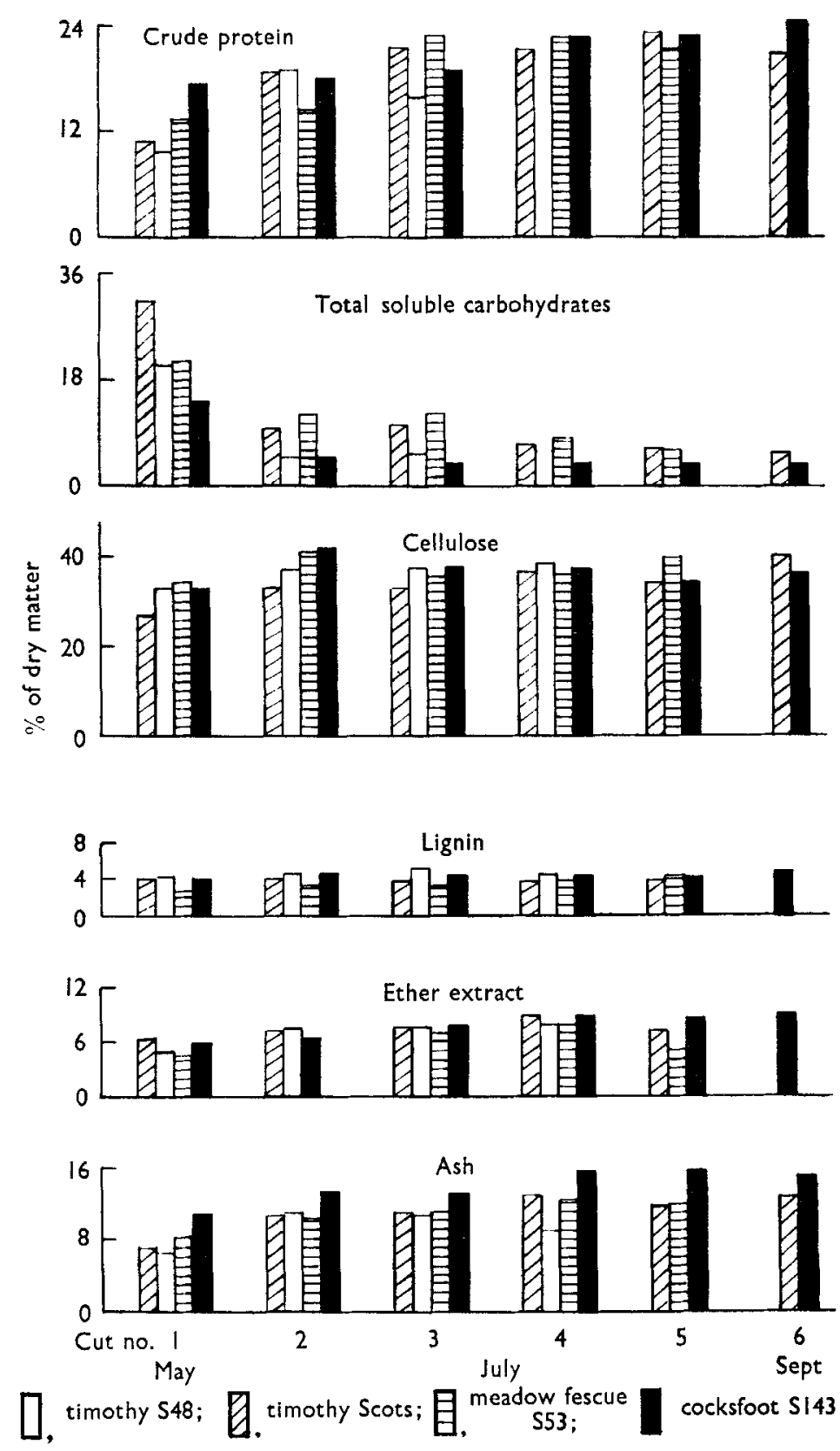

Fig, 2. Composition of timothy, meadow fescue and cocksfoot cut each time they reached grazing height. 
whereas in the first and, to a lesser extent, second cuts, the tillers carried small flower heads mostly unemerged. The change in the percentage of the soluble carbohydrates was the reverse of that for $\mathrm{N}$, being highest in the first or second growths and declining considerably thereafter, mainly because of a marked decrease in the reserve carbohydrate, fructosan. We have found that in vegetative grasses, or in grasses before head emergence, there is a strong inverse linear relationship between $\mathrm{N}$ and fructosan percentages. All the ryegrasses contained higher percentages of soluble carbohydrates than the timothy and cocksfoot grasses. In most of the grasses neither the cellulose nor the lignin contents changed greatly after the first cut, except to increase a little in the rather slower-growing last cut. Both the ether extractive and ash percentages were high, as would be expected from leafy material, and both increased in the later cuts. In all these results it will be noticed that there were considerable differences between species and also between varieties of the same species.

The feeding value of spring grass is often considered by graziers to be superior to that of the autumn growths. The values given in Figs. I and 2 show that, apart from slightly less cellulose in the spring grass, the major difference between such herbages would lie in the nitrogen and soluble carbohydrate fractions, spring grass containing much higher percentages of soluble carbohydrates and a higher ratio of sugars to protein. This in turn would lead to a rumen fermentation in which the proportion of propionic and butyric acid relative to acetic acid would be greater than from the summer and autumn grass, with benefit both for fattening (Armstrong, I964) and for milk composition (Rook \& Balch, i $96 \mathrm{r}$ ).

We were particularly interested in the high percentage of soluble carbohydrates in the first-cut spring grass, and, to determine whether first growth at any time of the year would possess a high value, $\mathrm{S}_{24}$ ryegrass was sown at monthly intervals from March to June. The grasses were cut when they had grown to a height of 8-9 in. and on analysis gave the values shown in Table $\mathrm{I}$. Being in their Ist year of growth, none of these grasses flowered, the primary growing point remaining small and undeveloped $(0.3 \mathrm{~mm}$ in length) up to the time of cutting. The results appear inconclusive if the percentage of total soluble sugars only is considered, but if the growths are judged on their capacity to store fructosan (the carbohydrate which normally accounts for the high value for soluble carbohydrates found in established spring

Table I. Effect of monthly sowings of ryegrass $S 24$ on the percentage of soluble carbohydrates in the first cut

\begin{tabular}{|c|c|c|c|c|c|c|}
\hline Date sown, & $\begin{array}{l}\text { Duration } \\
\text { of growth }\end{array}$ & $\begin{array}{l}N \times \\
6.25 \\
\end{array}$ & Hexoses & Sucrose & Fructosan & $\begin{array}{c}\text { Total } \\
\text { sugars } \\
\text { after } \\
\text { hydrolysis }\end{array}$ \\
\hline 1954 & (days) & \multicolumn{5}{|c|}{ ( $\%$ of dry matter) } \\
\hline I2 March & 96 & $17 \cdot 3$ & $2: 4$ & $2 \cdot 1$ & $4 \cdot 0$ & 9.0 \\
\hline Io April & 86 & $16 \cdot 5$ & $2 \cdot 5$ & $4 \cdot 5$ & $6 \cdot 2$ & $I_{4} \cdot 1$ \\
\hline I2 May & $6 r$ & $18 \cdot 5$ & $2 \cdot 9$ & $3 \cdot 2$ & $2 \cdot 8$ & 9.4 \\
\hline I2 June & 56 & I8.9 & $2 \cdot 7$ & $2 \cdot I$ & $I \cdot 4$ & 6.4 \\
\hline
\end{tabular}


grass) then the grasses sown in March and April contained more than the later growths. This was probably because of their slower growth, taking 96 and 86 days compared with the $6 \mathrm{I}$ and 56 days of the May and June sowings to reach the same height, thus allowing the accumulation of excess sugars to be stored as fructosan. The rate of growth of grasses has a marked effect on their content of soluble carbohydrates. We have shown, for example, that annual grasses, which in south-west Scotland flower about $5^{\circ}$ days after sowing, and first year grasses have much lower contents of soluble carbohydrates than established grasses and we have related this to their rapid rate of growth (Waite, 1957). Similarly, grasses such as cocksfoot and timothy grown quickly in a warm American climate (Phillips, Sullivan, Loughlin \& Sprague, 1954) had only about half the fructosan content of the same species grown by us. It seems probable, therefore, that the high fructosan and total soluble carbohydrate contents of spring grasses may be related not so much to flower production as to a slow rate of growth, at least until head emergence, caused by the generally low air and ground temperatures at that time of year.

\section{Grass grown for hay}

In making hay the farmer traditionally tries to obtain a high yield of dry matter per acre. This can only be achieved by cutting mature grass, which in turn leads to low-protein, high-fibre hay, often of low digestibility. Part of each of the grass plots used in the study of the composition of grazing herbage was also cut at the haymaking stage, i.e. about 10 days after most of the tillers had headed, and provided the values for composition given in Table 2. Despite the wide genetic differences, at this advanced stage of growth the percentages of $\mathrm{N}$, lignin, ether extractives and ash (except for cocksfoot) were very similar. The low values for $\mathrm{N}$, ether extractives and ash and the relatively high lignin percentages are typical of such material.

Table 2. Composition (\% dry matter) and yield (lb dry matter/acre) of grasses cut for hay

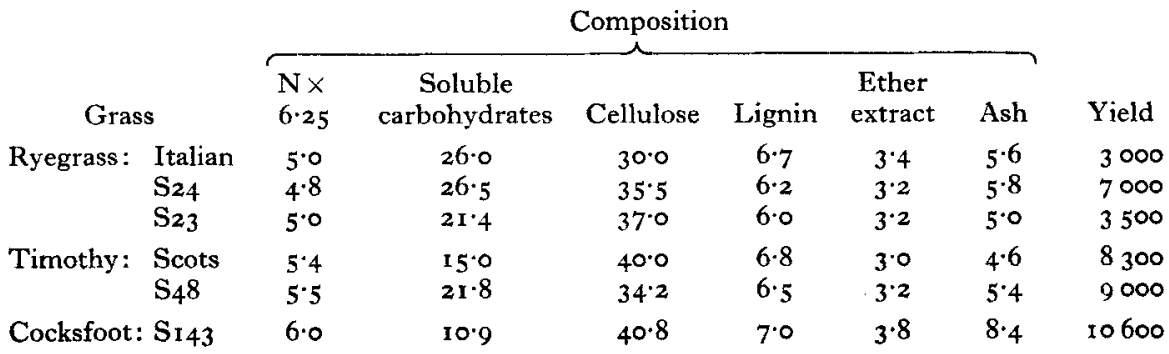

The soluble carbohydrate fraction provided the greatest differences between species, with cocksfoot again having by far the lowest percentage. It is true, of course, that this rapidly growing species would be expected to produce the highest yield of dry matter per acre (and it did), but the amount of hay given per day to livestock is limited and nutritionally, therefore, it is the percentage composition that matters. 


\section{The effect of wilting}

The values given in 'Table 2 represent the composition of the grasses as cut, with moisture contents of $70-75 \%$. Under weather conditions very favourable for haymaking the moisture content might be reduced to a sufficiently low value for storage of the hay in 2 days, but a period of $4-7$ days would be more likely. During part of that time respiration would continue in the cut grass bringing about some hydrolysis of sucrose and fructosan, loss of carbon dioxide and some breakdown of protein. In hay made in good weather in the field from the $\mathrm{S} 24$ ryegrass we found a reduction in fructosan content of $23 \%$ in $24 \mathrm{~h}$ and $35 \%$ in 4 days; Wylam (1953), using cut grass kept at $20^{\circ}$ in the laboratory, found a decrease in fructosan of $48 \%$ in 24 h and $64 \%$ in 8 days. By no means all this carbohydrate would be lost, as the fructosan hydrolyses first to smaller polymers and, based on the percentage of total soluble sugars, true losses of soluble carbohydrates in our material were only $10 \%$ after $24 \mathrm{~h}$ and $18 \%$ after $48 \mathrm{~h}$.

The changes in $\mathrm{N}$ distribution during wilting have been studied by Macpherson (1952) who showed that the extent of protein breakdown was also governed by the rate of drying. Reduction of the moisture content in cut grass from 80 to $60 \%$ in $24 \mathrm{~h}$ caused a drop in protein $\mathrm{N}$ (as a percentage of total $\mathrm{N}$ ) of $16 \%$ and an increase in non-protein $\mathrm{N}$, mainly in the amide and amino acid fractions. When, however, the moisture content was reduced artificially from 72 to $38 \%$ in $2 \frac{1}{2} \mathrm{~h}$ there was virtually no change in the $\mathrm{N}$ distribution. So long as adequate energy is available to the ruminant in its feed, non-protein $\mathrm{N}$ can be adequately utilized, and wilting therefore does not necessarily involve loss of $\mathrm{N}$, but the greater solubility in water of the protein-breakdown compounds makes them liable to leaching.

Wilting does, on the other hand, cause considerable loss of carotene from fresh grass. In warm sunny weather $\left(70^{\circ} \mathrm{F}\right)$ this loss amounted to $40 \%$ of that present in the growing grass in $24 \mathrm{~h}$ and $90 \%$ in $72 \mathrm{~h}$; under weather conditions less favourable to wilting $\left(55^{\circ} \mathrm{F}\right)$ the corresponding losses were $\mathrm{I} 8$ and $50 \%$ (Waite $\&$ Sastry, 1949 ). The growing practice of wilting grass before ensilage will certainly decrease the carotene content of this winter feed and, since most of the vitamin $A$ in winter milk is derived from the carotene of conserved herbage, losses such as those just given are an unfortunate concomitant of wilting.

\section{The effect of nitrogenous fertilizers}

I have limited this section to the application of inorganic $\mathrm{N}$, as the element to which grass most rapidly responds when growing in soil of adequate mineral and organic composition. The most obvious result is, of course, in the increased yield of dry matter, but this is accompanied by an increased ratio of leaf to stem and hence, in general, in higher protein and carotene contents. The results of Holmes (I949) and Stewart \& Holmes (r953) are typical. In their work, application of 3 r $2 \mathrm{lb} \mathrm{N} /$ acre, for example, raised the crude protein concentration of the grass dry matter from $\mathrm{I}_{3}$ to $22 \%$ and the carotene concentration from 320 to $440 \mathrm{mg} / \mathrm{kg}$, and maintained normal mineral balance so long as additional potassium was applied. The increased 
$\mathrm{N}$ content of the grass is accompanied by a rise in the non-protein (NPN) fraction. Ferguson \& Terry ( $195^{6-7}$ ), for example, showed that applications of 'Nitro-chalk' increased the proportion of NPN in the total N of grasses from 20 to $26 \%$ when applied early in the year and from 20 to $29 \%$ when applied late. A fertilizer rate of I $10 \mathrm{lb} \mathrm{N} /$ acre was also accompanied by an appreciable increase in the amount of nitrate $\mathrm{N}$ in the NPN. This result has been confirmed and the applications have been taken to higher levels by ap Griffith (1960) and ap Griffith \& Johnston (1960) who draw attention to the possible danger of nitrite poisoning after reduction of grass nitrate by rumen bacteria. Some years ago we studied the effect of the application of 2 and $4 \mathrm{cwt} /$ acre of a balanced fertilizer $(\mathrm{N}: \mathrm{P}: \mathrm{K}, \mathrm{I} 2: 4: \mathrm{I} 2)$ on the soluble carbohydrates of four species of grasses and found that in all species the percentage of total sugars declined as the rate of fertilizer application increased (Waite, 1958). This decline resulted mainly from the very much smaller accumulation of fructosan in the fertilized grasses and could again be linked with the correspondingly higher rates of growth. This is an important effect because the presence of an adequate supply of soluble carbohydrate in grass is essential for the production of good silage.

\section{The effect of ensilage}

In this section I do not wish to deal with the whole operation of converting grass into silage but only to emphasize the resulting changes in chemical composition. These have been widely studied, but probably the most detailed analyses are those published by the Edinburgh workers (McDonald, Stirling, Henderson, Dewar, Stark, Davie, Macpherson, Reid \& Slater, 1960), a single, slightly abbreviated

Table 3. Composition ( $\%$ dry matter) of grass and the silage made from it (From McDonald et al. r 960)

\begin{tabular}{|c|c|c|}
\hline \multirow[b]{2}{*}{$\mathrm{pH}$} & Grass & Silage \\
\hline & & $3 \cdot 7$ \\
\hline Dry matter $(\%)$ & 14.9 & $17 \cdot 4$ \\
\hline Organic matter & $88 \cdot 9$ & $86 \cdot 6$ \\
\hline Total N & $1 \cdot 92$ & $r \cdot 93$ \\
\hline Protein N & $\mathrm{I} \cdot 7 \mathrm{I}$ & 0.88 \\
\hline NPN & 0.21 & 1.05 \\
\hline Volatile $\mathrm{N}$ & 0.01 & 0.14 \\
\hline Total soluble carbohydrates & $17 \cdot 0$ & $\mathrm{I} \cdot \mathbf{2}$ \\
\hline Hexoses & $2 \cdot 7$ & \\
\hline Sucrose & $3 \cdot 2$ & 0.8 \\
\hline Oligosaccharides & $\mathrm{r} \cdot 6$ & \\
\hline Fructosan & $9 \cdot 5$ & 0.4 \\
\hline Total hemicelluloses & $12 \cdot 6$ & $9 \cdot 0$ \\
\hline Galactan & 0.7 & 0.4 \\
\hline Araban & $3 \cdot 0$ & $\mathrm{I} \cdot 6$ \\
\hline Xylan & $8 \cdot 9$ & $7 \cdot 0$ \\
\hline Cellulose & $24 \cdot 5$ & $26 \cdot 6$ \\
\hline Lignin & $7 \cdot 4$ & 6.8 \\
\hline Lactic acid & & xI'5 \\
\hline Acetic acid & & $2 \cdot I$ \\
\hline Butyric acid & & 0.2 \\
\hline
\end{tabular}


example of which is given in Table 3 . It is clear that the $\mathrm{N}$ and soluble carbohydrate fractions suffered most change, although there was even some hydrolysis of the hemicelluloses. The NPN, from a value of $1 \mathrm{x} \%$ of the total $\mathrm{N}$ in the grass, rose to $55 \%$ in the silage, and the total soluble carbohydrate percentage fell by $91 \%$ from the value in the grass. The lactic acid formed during fermentation in this well-made silage amounted to I I. $5 \%$ of the dry matter, but this compound has a lower energy value than the sugars from which it is derived and may, in addition, be leached from badly protected silage. These results show, I think for the first time, the extent of the hydrolysis of the hemicelluloses, particularly of the major constituent, the xylan.

\section{Conclusion}

A significant improvement in our agriculture in the last 20 years has resulted from the wider realization that, when grass is treated as a crop, greatly increased yields of dry matter can be obtained. With skilful management, the higher yields can be accompanied by improved chemical composition and nutritive value. In this paper I have emphasized the great variability in the composition of grasses produced by present agronomic practices and have discussed some of the causes of those variations. The possible nutrient loss that can arise from some of these practices has also been mentioned.

\section{REFERENCES}

ap Griffith, G. (ı960). F. Sci. Fd Agric. Ir, 626.

ap Griffith, G. \& Johnston, T. D. (1960). F. Sci. Fd Agric. II, 622.

Armstrong, D. G. (1964). F. agric. Sci. 63, 399.

Ferguson, W. S. \& Terry, R. A. (1956-7). F. agric. Sci. 48, 149.

Holmes, W. (1949). F. agric. Sci. 39, 128 .

Johnston, M. J. \& Waite, R. (1965). F. agric. Sci. (In the Press.)

McDonald, P., Stirling, A. C., Henderson, A. R., Dewar, W. A., Stark, G. H., Davie, W. G., Macpherson, H. T., Reid, A. M. \& Slater, J. (1960). Tech. Bull. Edinb. Sch. Agric. no. 24.

Macpherson, H. T. (1952). F. Sci. Fd Agric. 3, 365.

Phillips, T. G., Sullivan, J. T., Loughlin, M. E. \& Sprague, V. G. (1954). Agron. J. 46, 36 r.

Rook, J. A. F. \& Balch, C. C. (196r). Brit. F. Nutr. 15, 36 r.

Stewart, A. B. \& Holmes, W. (1953). F. Sci. Fd Agric. 4, 401.

Waite, R. (1957). F. Sci. Fd Agric. 8, 422.

Waite, R. (1958). F. Sci. Fd Agric. 9, 39.

Waite, R. (1963). Agric. Progr. 38, 50.

Waite, R. \& Gorrod, A. R. N. (1959). F. Sci. Fd Agric. ro, 308.

Waite, R. \& Sastry, K. N. S. (1949). F. agric. Sci. 39, I74.

Wylam, C. B. (1953). F. Sci. Fd Agric. 4, 527.

\section{The effect of soils, fertilizers and environment on the yield and nutrient content of plants: summing-up}

\section{By P. W. Arnold, Department of Soil Science, School of Agriculture, University of Newcastle upon Tyne}

All the subjects discussed at this Symposium bear directly on the fact that there is not sufficient food of high or low nutritive value to satisfy world needs. The yield and composition of plants have been considered in relation to the environment, the soiland what can be done to the soil in terms of irrigation, fertilizing and manuring- 